\title{
The Impact of Green Accounting for Reducing the Environmental Cost in Production Companies
}

\author{
Ali Mustafa Magablih \\ Irbid National University, Jordan
}

\begin{abstract}
Green accounting and their impact for reducing cost as a profession is the duty to improve the internal viewpoint of any economic unit and develop information that clarify its role within their environment and their contribution to providing appropriate information for decision-making which leads to the optimal exploitation of resources and the preservation of the environment and averting the threat. Thus, taking into account the environmental accounts especially environmental costs would enable the accounting profession to provide more relevant information and appropriate administrative decision makers, productivity, in particular where the problem lies in the lack of such information, resulting in the adoption of sound decisions which have contributed to the deterioration of the environment rather than addressed. In total, 180 questionnaires were distributed and 155 returned. Through analysis, the study came to the most important results that there were no statistically significant differences between the arithmetic average of the possibility of measuring the environment cost of disclosure, and the study also recommends the allocation of the budget to preserve and protect the environment and the budget of social cost, the development of accounting methods in order to provide environmental information to make sound decisions to exploit these resources.
\end{abstract}

Keywords: green, accounting, environment, production, responsibility

\section{Introduction}

Environment has become the issue practically with interest of the world, and has taken the nature of the interest in the ground breaking in multiple social and economic policies, and therefore, states were concerned with environmental issues, global organizations focused on environmental issues, and regional conferences have been held, interested in environmental services.

The scientific efforts in the field of management for the emergence of a new pattern of them under the name of environmental management have led to the emergence of environmental Accounting Advanced Accounting pattern, which some have called green accounting and has become one of the most prominent features of the development of contemporary accounting.

It is backed environmental pollution of phenomena which has received growing attention recently, especially in light of the industrial progress witnessed by our contemporary modern and new world is the new is the diversity of source of pollution and the harmful effect.

Based on the foregoing, a lot of organizations are demanded to protect the environment around the world and they need to commit industrial facilities to dispose of their waste in a scientific manner that does not threaten wildlife.

Ali Mustafa Magablih, Assistant Professor, Department of Accounting, Irbid National University. Email: alimagablih@yahoo.com. 
But the process of getting rid of these has become more a burden on these companies requiring disposal operations a lot of additional costs that may not born installations.

\section{Problem Under Study}

In the past few years, the interest of scientists and researchers to study environmental problems and find appropriate solutions to overcome them has increased and the United Nations played a prominent role in this regard. Attention has been given to the problems of environmental pollution and environmental development of the Champions Trophy by the United Nations Environment Program which is interested in studies and research of environment and creation of effective positive solutions to protect the planet from environmental pollution.

According to the report of the World Bank on environmental strategy for the Middle East and North Africa, the Arab world faces an environmental disaster, the most important in the air and water pollution and land degradation, which cost the Arab world more than $\$ 10$ billion annually, equivalent to 3\% of the total national income, pointing out that there are about 60 million people in the Arab world who do not have access to clean water, and that more than 25 million people are living in the cities where the pollution levels are not allowed in the world.

Environmental pollution is one of the most important problems of the contemporary world at the international and regional levels, even in the developed industrial countries and developing countries looking for the imbalance between the elements of the environment, and so many conferences, seminars, and conventions are held, of which the most important is the Stockholm Conference in 1972, which stressed the need for the link between the environment and development, as recommended by the Conference of Rio de Janeiro in 1992, also known as the "Earth Summit", on land and natural resources to achieve development in the context of the objectives of the environment and conservation as well as the climate conference in Japan in 1997, which focused on the need to reduce emissions of carbon dioxide for the preservation of the environment.

There is an agreement among contemporary economists on the importance of replacing market mechanisms and government intervention as an alternative to the allocation and use of natural resources owned by groups, forcing contaminated facilities to reduce external costs and pollution associated with an inefficient use of these resources. Considering this, there are many methods of government intervention in this area: the famous one is the use of various economic policy instruments, including tax policy.

\section{Research Objectives}

This research aims to achieve the following objectives:

(1) A statement of the need for environmental cost accounting;

(2) The study of methods of measurement and analysis of the elements of the environmental costs;

(3) A statement of the role of the advanced methods of production in the presence of environmental costs.

\section{Plan of the Research}

Theoretical side: it was a study of major ideas in different theoretical aspects where the researcher addressed the definition of green accounting, environment, and pollution to evaluate the cost of environment pollution.

Practical side: the study population and sample and measurement tools and the data collection method and statistical method are used to analyze the data and result. 


\section{Significance of the Research}

The importance of this research lies in addressing one of the most important issues facing the industrial facilities at the present time which is how to reconcile the reduction of environmental pollution and achieve a remarkable level of environmental quality in return, reducing environmental costs under the competition faced by enterprises at the present time.

\section{The Hypotheses of the Research}

The research is based on several assumptions that:

(1) The economic unit that can affect the protection of the environment through reducing the cost of environmental pollution;

(2) The attention of managers to reduce the risks faced by workers and the community from environmental pollution;

(3) Use a variety of methods of accounting for the environment to highlight the extent of the contribution of the economic unit to carrying out its responsibilities toward the community.

\section{Literature Review}

The study entitled, The Importance of Disclosure of Environmental and Social Responsibility in the Financial Reports Published in the Kingdom of Saudi Arabia. Where an exploratory study of four categories: academics, investors, accountants and lawyers toward disclosure of installations in the Kingdom of Saudi Arabia and distributed to the four categories mentioned. The study found that enhancing the reputation of the community and the absence of legal requirements is one of the most important reasons for non-disclosure of this type of information, and that the appropriate place for the disclosure of this information, from the point of view of the participants in the study, is the report of the Governing Council.

Abu Zaid's (2007) study, entitled Proposed Accounting Framework of Disclosure of Environmental Performance Under the Environmental Quality Standards, aimed to shrug off the P-4 level of the accounting disclosure of environmental performance in the financial lists, and those lists reveal the facts of the operations carried out by the project at the end of a certain period of time, the study of the accounting standards relating to the disclosure of environmental performance, matters through the financial lists in general. The main results of this study are as follows: The inadequacy of the foundations and rules of measurement and presentation of the overall social costs of environmental damage arising from the operations of the facility.

The study, entitled Accounting Measurement of the Costs of Environmental Pollution Damage to Workers in the Oil Refinery Sector, attached importance to the recognition of the environmental expenses in the oil refinery sector, indicating the importance of accounting measurement of environmental costs in the oil refinery sector, and how to measure the cost of environmental pollution and the diseases that afflict the workers in the oil refinery sector. The study came to the set of results, the most prominent of: The possibility of measuring the cost of diseases of environmental pollution for workers, by measuring the cost of treatment, health care, and the cost of wages paid during the duration of the treatment and similarities of healing, and quantify the value of the energy shortfall in productivity due to the absence of workers, and quantify the value of the shortage in the capital value of the human resources. The possibility of measuring the cost of early death of workers from illnesses environmental pollution in the company. The study concluded several recommendations, the most important being the development of the company's financial accounting system so that it can be through the 
preparation of reports of environmental accounting and disclosure of qualitative and quantitative information and financial cost tab to include environmental costs.

\section{Environmental Cost}

This tells us that the handling of the nature of environmental pollution in terms of the concept of the environment and environmental pollution, the types and sources of risks of contamination, as well as the impact of environmental pollution on development.

\section{The Concept of Environmental Pollution}

The most important definition of environmental pollution is as follows:

(1) Pollution is corrupting the environmental components, so as to turn from useful elements to harmful elements, its resources, air and soil, often by rights through neglect or abuse;

(2) Pollution is the accumulation of harmful microorganisms and other elements such as concerts because they use energy, too;

(3) Pollution is the introduction of materials or energy in the environment through the rights which may be the cause of human health risk or harm of live material and ecosystems or damage to buildings or aspects of the hearing, or incompatibility with the correct uses of the environment.

Environmental pollution also leads to many social effects, the most important of which are the following:

(1) Damage to public health;

(2) Unequal luxury where harm is the biggest burden on low-income groups, and that the damages caused by the contamination and destruction of the environment which affect humans, plants and animals, are not taken into account as one of the elements of prosperity;

(3) The increase in the cost of cleaning operations and repairing damage to buildings and property.

\section{The Nature of the Environmental Costs}

Identifying environmental expenditures so as to facilitate the measurement and analysis to help determine the total expenses when they occur, and then the tab for these expenditures in general, and at the same time, specialized, depends on the source of the occurrence through regulation, which was causing the occurrence, thus facilitating the preparation of reports of environmental costs and the reports of different administrative levels, specializes in this point, study and analysis of the concept of environmental expenditures, compilation, the Champions Trophy as follows.

\section{Accounting Measurement and Disclosure and the Role of Accounting Standards in the Area of Environmental Cost Accounting}

This section mainly deals with accounting measurement of environmental costs, accounting and disclosure of environmental costs, and the role of accounting standards in the field of cost accounting of environmental accounting measurement of environmental costs.

Attention is the identification and measurement of environmental costs and the phenomenon of his relatively where the companies concerned environmental pollution and that it was not interested in the emissions of noxious fumes which pollute the air or discharge of waste in rivers, which threatens the safety of the organisms and therefore there is no disciple learns of the existence of the territory of untapped due to environmental pollution and the high cost of removal of the manifestations of this pollution does not convince the management of companies to undertake clearance activities. 
Gradually, there is a growing need to live in a clean and safe environment, especially with the appearance of some laws for the protection of the environment while also paying more attention to environmental disasters and focusing on the development of methods to measure and manage the environmental costs, especially with the emergence of new specifications of ISO 1400 which require companies to exercise environmentally friendly activities in different production and marketing operations.

\section{The Method of Quantitative Measurement}

The quantitative measure that the set of objects or events according to specific rules includes measurement systems:

(1) The measurement system is based on the hierarchy where objects or events are arranged and grades are given according to the greater or smaller than the content of the property to replace the instrument cluster;

(2) The measurement system is used to determine the deviation from the standards set by law the impact of some environmental processes such as the legally prescribed ratio;

(3) The relative measurement system is used to measure the results of environmental performance in some cases, such as determining the rate of recurrence of infection which demonstrates the multiple injuries to the employees of the project during a certain period of time.

\section{The Steps in Determining the Environmental Costs}

Environmental costs are identified in the following steps:

(1) Step 1: the expense of environmental costs. In this step, the environmental costs of any project by identifying the primary situation of the environmental situation or the current situation following the measurement of any changes in environmental case expenses which is the implementation of the measurement, as additional expenses for primary situation environmental costs can be summarized as follows:

(a) Identify the regular costs such as wages and direct materials used and the equipment used;

(b) Identify the indirect costs such as environmental reporting, environmental monitoring, and license fees.

(2) Step 2: Measuring the cost of the implementation of the laws of the receiving environmental commitment: such as the cleaning of generators of harmful emissions of pollutants, injuries to individuals, damage or loss of the machines.

The foregoing summarizes that the cost of the first step covering primary situation, the costs of the second step are the traditional costs, the costs of the third and fourth steps, such as the non-advanced costs (indirect) which identified more difficult and include:

(1) The compensation claimed by others;

(2) Judicial proceedings against personal or property damage;

(3) Although these costs are difficult to measure accurately, it may be very important;

(4) The accounting treatment of environmental costs;

(5) Divided into environmental costs for assets used in the production processes or expenses that are consumed during the period. Accounting can be addressed as follows:

The costs for fixed assets:

Since it was mostly used as one of the durable assets that belong to the intangible fixed assets used in production processes for long periods, the cost of its elements does not differ from the process of measuring other fixed assets at any measurements of the assets (i.e., is consumed in the same way as the consumption of fixed assets), which belong to two types: 
(1) Is usable once purchased and transferred to the appropriate place for operational processes and therefore costs equals purchase price in accordance with the purchase invoice plus transportation and installation costs and insurance;

(2) After its purchase and transportation needs to some of the expenses necessary for the process of running costs be comprehensive and, therefore, the purchase price plus all expenses necessary for the process of experimentation and other operating expenses.

Thus, the quality of these assets is being measured as already judged in accounting as new assets to be added to the assets of the economic unit which is allocated to consumption expenses to the accounting periods (the length of the productive life of the asset), an application of the rule of entitlement is accounting for depreciation in the premium part of the costs of the period.

The expenses of pollution reduction:

All costs and expenses are intended to ozone which is deducted from the income of the period of pollution abatement expenses which are divided into two sections, namely:

(1) The expenses spent directly by the economic unit in the area of pollution reduction and all the expenses spent in removing environmentally harmful waste in the accounting period of the taxpayers who bear the expenses to the profit and loss account which is a tool for the same period. The reason is that the previous disbursements expenses taxpayers is ending came after the production process and therefore cannot be considered elements of the cost of the direct production but can be considered indirect expenses. For this reason, they are carrying on the profit and loss account and the operating account may be overloading;

(2) The expenses paid by the economic unity of the official authorities competent in the field of pollution reduction.

Accounting disclosure of environmental costs:

According to US Financial Accounting Standards Board (FASB) accounting standard No. 1, the purpose of the lists and financial reports is to offer all current and prospective investors and creditors useful information which will help them to take sound decisions and so that this information is understood to be used and these lists and reports offer both investors and creditors other information on cash flows expected return to the attic of their investments or interest on their money that loan, and must explain property rights and the rights of others and any other obligations in addition to the impact of economic events on these rights and ways are also found to get the resources and how to use it in the form of different origins as well as any information in performance assessment and forecasting future profits, and the importance of accounting disclosure of environmental costs can be studied through the following points:

The importance of disclosure of the costs of pollution reduction:

Emerged in recent times the importance of disclosure of environmental information and the importance of appropriate environmental behavior for the following reasons:

The development of the criterion of public disclosure through the expansion of the data and information to be disclosed in form and content, to include the economic and environmental performance of the enterprise.

The needs of the users of financial lists of environmental information, where investors may have known about the investment in the shares of companies that do not disclose environmental performance to a threat to the continuation of the business as a result of the collapse of the debtor or consumer boycotts of their products which are harmful to the environment. 
The rationalization of the economic decisions of users of financial statements with regard to the assessment of the extent to which established its responsibility toward the preservation of the environment from pollution and increasing community confidence in facilities that meet environmental responsibility and encourage them to develop their activities, with pressure on facilities that do not fulfill that responsibility.

Different dimensions and trends have emerged in the field of disclosure of environmental performance as a result of the studies of applied models which can be summarized as follows:

Terms of pronunciation of disclosure.

Affect the nature of the activity of the organization and the society which engaged in its work on the scope or extent of disclosure of environmental performance information and takes the following forms:

The disclosure of environmental costs only without the disclosure of the value of the environmental benefits because of the difficulties in measuring such benefits and could be disclosed in the financial lists traditional or in separate reports:

Reports on the amount of... Containing quantitative information on environmental performance, such as the amount of emissions, the quantity of waste, etc..

Financial reports... Where we can get information on environmental performance in the financial picture to determine the cost-benefit analysis of environmental activity.

Disclosure of environmental performance within the reports of the independent from traditional menus and accessories, or within the organization's social reports. This method is based on the design of social and environmental reports separate from the financial reports as a means to show the economic unity of the social and environmental responsibility. Therefore, there are three types of reports as follows: (1) descriptive reports on social and environmental performance; (2) reports on the social and environmental costs; and (3) reports of the profit rate the costs of social and environmental performance. These reports can be explained as follows:

Firstly: descriptive reports on social and environmental performance include separate descriptive reports on financial reports which reflect the social and environmental performance and describe the activities of the social, environmental and economic unity which is considered one of the most basic social and environmental reports and takes the form of a budget model including two aspects: the assets side describes the positive effects of social activities and liability side describes the negative effects of social activities. So this is the kind of primitive input social reports because of the department and the other social communities to assess the environmental performance of the company as it contains a description.

One of the areas of social activities does not include any measure, in quantitative terms. Most of the elements of the model did not define its monetary values, and the monetary values covered by this report are limited.

Secondly: reports on the social and environmental costs: The reports of the social and environmental costs include the social and environmental costs of activities performed by the economic unity of the fulfillment of the social and environmental separate reports on the financial reports to be prepared periodically. Various versions of financial lists were published and contain three sections established in relation to each of the individuals, the environment, the product, and the preparation of the list group responsible within the economic unit including different specialties: one of the managers of the company, a specialist in sociology, a specialist in public health, and a specialist in economics and there is an accountant at the head of this group. This list reviews the independent foreign group headed by a legal auditor and this group includes different specialties as needed. But there are several reviews on this list: (1) this is the list of additional menus outside statistical 
accounting system, and outside the basic financial statements, but may request the type of disclosure of the role of the economic unit in the service of society and the environment, and it should be noted that the first accounting standard requests such a list, but optional; (2) rename the list of social activity whereas the goal of which is to provide information about the social and environmental activities together, and it is already included information about the social and environmental activities of the list which was preferable social and environmental activity; (3) the objective when the definition of damage, social and environmental cost, because the definition of the cost of the damage as the cost avoid established as a result of the lack of implementation of certain behaviors, marred by the same gaps that result from the application of the concept of the cost of preventing damage. Both concepts do not reflect the social and environmental cost resulting from the exercise of the established activity from the point of view of the community; and (4) limiting the model to view the social costs of the environment only, and not be familiar with him from the judgment on the efficiency of the social and environmental performance for economic unity, which does not explain the extent of the impact of the degree of efficiency of the economic unit on environmental expenditures in the area of social performance, and it is considered that the unity that spent large sums are more environmental performance regardless of the amount of achievements in the field of social and environmental performance.

Thirdly: report of the profit rate and the costs of social and environmental performance. These include the actual costs borne by the economic unit in the areas of various social performance, whether related to the mandatory or optional activities that this list contained inside the following costs: (1) the costs of social activities of the interior of the facility with the distinction between the costs of social assessment activities and the costs of the optional social activities; and (2) the active social costs in the area of outer social performance with distinction between mandatory social costs of activities and the costs of the optional social activities. The following is the illustration of the model:

The role of accounting standards in the area of environmental cost accounting: there is global interest in environmental accounting, whether at the international or domestic level. Some of these are: (1) In the United States of America: The United States of America is most interested in the measurement of environmental costs through the efforts of both U.S. Securities and Exchange Commission (SEC) ${ }^{1}$, the US accounting standard setter FASB ${ }^{2}$, and the American Institute of Certified Public Accountants (AICPA) ${ }^{3}$.

\section{The Role of the Advanced Methods of Production in the Light of Environmental Accounting}

First: The entrance of the product life cycle to improve environmental performance:

Stage 1: The design phase;

Stage 2: The stage of the acquisition of raw materials and energy;

Stage 3: Stage of industrialization;

Stage 4: The mobilization phase;

\footnotetext{
1 The SEC issues bulletins to express the special environmental disclosure of the contents of the financial lists of companies and the disclosure on the measurement of environmental costs in order to serve parties benefiting from the information of published financial lists especially investors and recipients.

${ }_{2}^{2}$ FASB issues accounting standard No. 5, "Accounting for Emergency" in which we should be alert to the importance of the instrument panel and the disclosure of environmental costs.

3 AICPA issued a standard to address environmental obligations, the most prominent of this standard, the importance of the growing role of the accounting and auditing profession in the preparation of environmental reports. This criterion was also interested in addressing environmental obligations so as to include the fixed assets budget for dealing with environmental obligations, and include the income list of environmental expenses during the period.
} 


\section{Stage 5: Stage use;}

Stage 6: Stage of exclusion (the disposal of the product).

For the goal of reducing the environmental costs of the objectives to be achieved, the Department established the process of measuring the environmental costs which is the first step to achieve this goal, and to follow the stages of the product life, the Department established the activities that cause or increase the proportion of environmental costs. The researcher sees the importance of a study of the cost-accounting system on the basis of the activity and how it can contribute to the allocation of environmental costs, especially of most of the elements of these costs directly, the cost of the product's life cycle as the cost is important, particularly in industries that are the costs of planning and development. First: The entrance of the product life cycle to improve environmental performance is to know the environmental costs of the product key in most improvement opportunities whenever acquired established experience in identifying these costs could increase this experience using the entrance of the product's life cycle, where the assessment process determines the life cycle of the environmental consequences of a product through the full life cycle and then search for opportunities for environmental improvement. The environmental costs associated with waste and waste treatment and disposal of toxic waste and environmental audits are an important part of the costs of the life cycle of many products and there is no doubt that the inclusion of environmental expenses as part of the cost of the product's life cycle which can show that the product is the acquisition cost less environmental costs.

The cost of the product's life cycle is the process of assessing and compiling the costs over the life cycle of the product as a whole and identify the cost is important, particularly in industries that are the costs of planning and development, or if the costs of disposal of the product are high, there are three benefits of the analysis of the cost of the product's life cycle:

(1) Help the entrance to the cost of the life cycle in the development of the meaning of the overall costs associated with a product to identify whether the profits achieved during the manufacturing phase will cover the costs in the stages of development and exclusion;

(2) Because of the overall view of the costs, the entrance to the cost of the life cycle will explain the results of the environmental cost of a product, and will be looking to reduce or restrict those costs;

(3) Help the entrance to the cost of the product's life cycle to identify the costs of planning and exclusion during the two stages of the product design and the productive process for the control and management of costs at this stage. The product life cycle analysis helps identify the potential causes of pollution and how to prevent their life cycle can be divided into six main phases.

Stage 1: The design phase. In the design phase, most of the environmental costs occur over the stages of the life cycle of the product determined and implied through the stages of the detailed design of the product, where the design of contamination outside the product is pollution control through all the stages of the product life cycle. Therefore, the attention to this stage and work on product design and non-polluted environment can reduce environmental degradation and that the decisions taken at this stage are crucial decisions as to any additional amount is spent on the product at this stage would be provided in the special environmental costs in the production or post-production.

There is a set of standards for product design, which can be taken into account in the choice between several possible design alternatives and potential:

(1) The use of materials that can be recycled;

(2) Reducing the use of toxic solvents or replaced with alternative; 
(3) The re-use of waste;

(4) Use of materials based on the water instead of solvent based materials;

(5) Use of a range of products and packaging requirements;

(6) The manufacture of final products can be recycled.

The main elements of the environmental costs of this phase are as follows:

(1) The costs of the activities of the research and development necessary to determine the requirements of the environmental quality of the product;

(2) The costs of the activities of the product design or production processes. The costs of the selection or design components or raw materials required for the essential parts of the product or service;

(3) The costs of the analysis of risks related to the safe use of the product or service. The costs of the analysis of the viability of the product for reuse or recycling. Therefore, the greatest impact on environmental costs occurred during the design stage of product development and consequently the concept of "Design for the environment", which aims to reduce errors and costs early in the design phase.

Stage 2: The stage of the acquisition of raw materials and energy. At this stage, greater opportunity to reduce negative environmental impacts helps reduce:

The costs of environmental purification (costs of addressing environmental pollution) and manufactured products from non-recyclable materials and products are polluting and therefore the selection of the appropriate resource, which is providing non-polluting materials and components of the environment. Or the treatment of the material purchased so that there is less contamination of the environment as well as access to clean energy sources and non-polluted environment provides an appropriate opportunity to minimize the occurrence of environmental pollution and the costs of treatment and purification of the environment from the pollution and then.

The elements of the environmental costs are as follows:

(1) The cost of checking the suppliers to review and evaluate the capacity of both the supplier and the requirements of the environmental quality of the enterprise. The cost of the conformity of the parts and materials purchased with لمحددة requirements with a view to reducing the impact of the lack of conformity of these components on the quality of the product or the environment. The cost of planning, testing and deliveries, whether the property or the supplier in order to determine the degree of acceptance of the supplies;

(2) The cost of the activities to make sure the capacity of the methods, processes, equipment and machinery for the good production and match the transboundary environmental. The cost of official training programs for workers in order to prevent operating errors and how to deal with the supplier and harmful and toxic and increase awareness of environmental requirements.

Stage 3: The manufacturing phase. The manufacturing processes are direct sources of many of the solid, liquid and gaseous wastes, many of which are disposed of in the environment. They may also occur as a result of the use of pollutants and types of energy causing environmental pollution, as well as pollution may occur as a result of the use of the machines, causing environmental pollution or causes chemical pollution.

The program for the protection of the environment has referred to the necessity of manufacturing of products at the expense of damage to the environment, and even this can be achieved must be:

(1) Used in the production of materials contaminated the environment;

(2) Restrictions on the issuance of harmful emissions to the environment from industrial processes;

(3) The conduct of remnants of manufacturing operations at the expense of damage to the environment;

(4) Work on recycling or re-use of waste produced from manufacturing processes. 
Interest in environmental affairs has been accompanied by the emergence of modern technological equipment and reduction of waste and emissions during the production processes which lead to maintaining the internal environment of the facility, thus reducing the potential risks of workers and damage to the external environment.

Stage 4: The mobilization phase. It must be pointed out that the operations of productivity (in the manufacturing phase) are not the only source of environmental cost in the United Kingdom which is $30 \%$ of solid waste in packaging materials. It is therefore important to focus on the need for the product in the packages, which are harmful to health, which requires the manufacture of the device without the use of components of toxic or dangerous substances, and that these devices are recyclable or reusable, without risks to health so do not represent an environmental burden when disposed of.

Stage 5: The stage of use. The use of the product to the harmful emissions that lead to the pollution of water or air, soil and can reduce these emissions certainly on the efficiency of the purchased material so that it does not include the constituent elements of the product harmful materials for human beings not waste or product can be recycled waste.

Stage 6: Disposal of the product. After using the product that could get rid of this product by the customer to environmental degradation, whether the components of the product are recyclable or reusable, manufactured products from easily recyclable materials are relatively non-polluting products.

There is no doubt that the costs of disposing of a product will vary from product to product, and the costs of disposing of the products of the impact on the environment (toxic chemicals, nuclear waste and the offspring) would be very high compared with other products.

And we should make use of waste resulting from the production processes of re-used or recycled rather than disposed of in the environment and help the use of modern technological methods until the disposal of such waste by turning it into a secondary product, which also reduce the overall cost of genuine products.

The department is focusing on environmental costs during the life cycle of the product as preventative costs where these costs represent the activities to be carried out at every stage of the life cycle of the product to prevent low-quality environmental performance and environmental pollution, thus avoiding the costs of addressing environmental pollution or the costs of not responding to environmental requirements or compensation, fines and penalties as a result of the environmental performance of the non-legal patients.

Second: The cost-accounting system on the basis of the activity:

Know the cost-accounting system on the basis of the activity as "accounting system and measuring the cost of the resources consumed by activities, and measure the facility costs very accurately and better quality of traditional cost systems, and address the problem of arbitrary allocation of costs, through the classification of activities, and then follow the costs to activities through cost-engines, where activities performed within the established several levels are classified: activities at the level of the unit of production, activities at the level of the productive installment, activities at the level of products, and activities at the facilities. The system uses the concept of activities that do not add value to the product, where the assessment of a variety of types of these activities to be defined by the administration to try to excluded or reduced, the system is developed in the procedures for allocating indirect costs to products, focusing on the activities performed for the production of the product, and the extent of the benefit of these activities. Thus, we build a cost-accounting system on the basis of the activity on the following several assumptions:

(1) Economic activities that consume resources; 
(2) Products or services that consume activities;

(3) The consumption of economic resources has many causes;

(4) The activity that can be defined and measured;

(5) There is homogeneity between cost-complexes.

Based on this, we can say that the cost accounting system on the basis of the activity adopts the idea that the products or services consumed the activities rather than economic resources, and that those activities consume resources of indeed, and the application of those basic ideas, it helps to achieve the three objectives of cost accounting: the cost metric, the control of its elements, the provision of relevant information and the desired characteristics of decision makers within the economic unit.

Many organizations in the current time use the cost-accounting system on the basis of the activity as an alternative to traditional cost accounting system.

Through a review of the environmental costs, we find that most of these costs are indirect costs that the researcher sees that it is appropriate to use the cost-accounting system in the allocation of environmental costs, which achieve the following benefits:

(1) Download each product including consumed by environmental costs;

(2) An attempt to exclude or reduce the activities that cause high environmental costs;

(3) Reduce or exclude products that cause high environmental costs.

\section{Statistical Analysis and Results}

\section{Analysis of the Study}

The study consists of production companies in Jordan. The study sample includes financial managers to whom 180 questionnaires were distributed and 155 returned.

Table 1

Member of the Study by Gender

\begin{tabular}{lcc}
\hline Sex & Frequency & Percentage (\%) \\
\hline Male & 145 & 94 \\
Female & 10 & 6 \\
Total & 155 & 100 \\
\hline
\end{tabular}

Table 1 shows that the highest frequency of sex (male) in the sample reached 145 (94\%), followed by female (10) with a percentage of $6 \%$.

Table 2

Member of the Study by Qualification Degree

\begin{tabular}{lcc}
\hline Qualification degree & Frequency & Percentage (\%) \\
\hline Diploma & 4 & 3 \\
BA & 143 & 92 \\
Master's degree or above & 8 & 5 \\
Total & 155 & 100 \\
\hline
\end{tabular}

In Table 2, BA (92\%) reaches the highest frequency (143) in the sample.

The distribution of the sample depending on the monthly income is shown in Table 3.

Table 3 shows that the highest frequency (133) in the total sample is reached by income of more than 451 dinars with a percentage of $85 \%$. 
Table 3

Member of the Study by Income

\begin{tabular}{lcc}
\hline Monthly income & Frequency & Percentage (\%) \\
\hline Less than 250 JD & 4 & 3 \\
251-450 JD & 18 & 12 \\
More than 451 JD & 133 & 85 \\
Total & 155 & 100 \\
\hline
\end{tabular}

Table 4

Averages and Standard Deviations (The Possibility of Measuring the Environmental Costs of)

\begin{tabular}{|c|c|c|c|c|}
\hline No. & Paragraph & $\begin{array}{l}\text { Standard } \\
\text { deviation }\end{array}$ & $\mathrm{P}$ & $\begin{array}{l}\text { The degree of } \\
\text { evaluation }\end{array}$ \\
\hline 1 & $\begin{array}{l}\text { Accounting has been able to develop accounting method to } \\
\text { measure the expenses incurred by the economic unit to } \\
\text { remove the impact of environmental pollution caused by its } \\
\text { activities. }\end{array}$ & 1.01 & 1 & High \\
\hline 2 & $\begin{array}{l}\text { The equation to calculate the fine must be paid by the } \\
\text { economic unity of the official authorities competent in the } 4.10 \\
\text { field of reducing pollution. }\end{array}$ & 1.04 & 2 & High \\
\hline 3 & $\begin{array}{l}\text { The development of the concept of appropriate disclosure } \\
\text { and its criterion, including international commensurate with } \\
\text { the social activities exercised by the economic unit to } 4.00 \\
\text { reduce pollution, and on the impact on the reports and lists } \\
\text { prepared by the projects. }\end{array}$ & 1.06 & 3 & High \\
\hline 4 & $\begin{array}{l}\text { The concept of social cost accounting in general and the } \\
\text { cost of environmental pollution that could be included in } 3.97 \\
\text { the current intellectual framework of accounting. }\end{array}$ & 1.14 & 4 & High \\
\hline 5 & $\begin{array}{l}\text { Accounting was able to know the impact of the costs of } \\
\text { environmental pollution on financial lists and changes that } 4.10 \\
\text { can occur on such lists. }\end{array}$ & 1.04 & 2 & High \\
\hline 6 & $\begin{array}{l}\text { The problems that require accounting for environmental } \\
\text { costs are the modern environmental accounting and the } 3.58 \\
\text { present time. }\end{array}$ & 1.18 & 6 & High \\
\hline 7 & $\begin{array}{l}\text { The procedures for the measurement of social responsibility } \\
\text { and accountability of the various elements which had not } 3.13 \\
\text { received adequate attention and care. }\end{array}$ & 1.38 & 9 & Medium \\
\hline 8 & $\begin{array}{l}\text { The shift toward the cost of environment as a part of the } \\
\text { production cost led to the entry of the social costs of the } 3.48 \\
\text { accounting function. }\end{array}$ & 1.46 & 8 & High \\
\hline 9 & $\begin{array}{l}\text { The acceptance of the mandate to protect accounting } \\
\text { community resources makes it imperative to develop its } \\
\text { methods to provide environmental information in order to } 3.52 \\
\text { take into account when making decisions the exploitation of } \\
\text { these resources, assessment and follow-up of this } \\
\text { exploitation. }\end{array}$ & 1.21 & 7 & High \\
\hline 10 & $\begin{array}{l}\text { The case of the report on the environmental and social } \\
\text { information part of the accounting principles and the level } 3.87 \\
\text { of review. }\end{array}$ & 1.23 & 5 & High \\
\hline 11 & $\begin{array}{l}\text { The results of the activities related to the measurement of } \\
\text { impacts which is essentially about the environmental, } 3.87 \\
\text { social, and economic interest of the inclusion of the effects } \\
\text { of the project on the quality of life in the community. }\end{array}$ & 1.15 & 5 & High \\
\hline 12 & $\begin{array}{l}\text { The extension of the scope of results of measuring } \\
\text { environmental and social responsibility to include many of } \\
\text { the parties in addition to having the project financial } 4.00 \\
\text { relations. }\end{array}$ & 1.00 & 3 & High \\
\hline & Average & 0.39 & & High \\
\hline
\end{tabular}


To test the first hypothesis, arithmetic averages, standard deviations, and the aggregate total of all the paragraphs of the field possibility were calculated (see Table 4).

As shown in Table 4, the highest average is "the possibility of measuring the environmental costs" of Paragraph 1, which provides "accounting was able to develop accounting method to measure the expenses incurred by the economic unit to remove the impact of environmental pollution caused by its activities" (4.19), followed by Paragraph 5 (accounting was able to know the impact of the costs of changes that occur on those lists) with an average of 4.10. Paragraph 7 (The procedures for the measurement of social responsibility and accountability of the various elements which had not received adequate attention and care) is below the average (3.13).

Table 5

The Results of the Application of the Test (One-Sample T-test) - The Possibility of Measuring the Environmental Costs

\begin{tabular}{lllllll}
\hline Area & Average & $\begin{array}{l}\text { Standard } \\
\text { deviation }\end{array}$ & $T$ & $\begin{array}{l}\text { Degrees of } \\
\text { freedom }\end{array}$ & $\begin{array}{l}\text { Statistical } \\
\text { significance }\end{array}$ & The result \\
\hline $\begin{array}{l}\text { The possibility of } \\
\text { measuring the } \\
\text { environmental costs }\end{array}$ & 3.82 & 0.39 & 11.5 & 30 & 0.05 & $\begin{array}{l}\text { The refusal of the } \\
\text { zero hypothesis }\end{array}$ \\
\hline
\end{tabular}

Table 5 shows that the $T$-value of the possibility of measuring the environmental costs reached 11.5, which is the value of a function at the statistical significance level of $a=0.05$. Scalable Link Interface (SLI) five brand standard (3), with the arithmetic average for the domain (3.82) the degree of high assessment indicates the existence of the possibility of measuring environmental costs and disclosure at the statistical significance level of $a=0.05$. Therefore, we reject the zero hypothesis and accept the basic premise of the first.

The second hypothesis is: there were no statistically significant differences at the level of significance $(a<0.05)$ in the views of the members of the sample on the possibility of measuring the environmental costs by depending on personal variables.

To verify the second hypothesis, we used the Independent Samples Test (the attention of managers to reduce the risks faced by workers and the community from environmental pollution) and made an analysis of variance (ANOVA unilateral), arithmetic averages, and standard deviations to determine the feasibility of measuring the environmental costs of disclosure related with the variable degree the monthly income.

Table 6

The Results of the Test (Independent Samples Test) Depending on the Variant of Sex

\begin{tabular}{lllllll}
\hline Area & Sex & Average & $\begin{array}{l}\text { Standard } \\
\text { deviation }\end{array}$ & $T$ & $\begin{array}{l}\text { The degree of } \\
\text { freedom }\end{array}$ & $\begin{array}{l}\text { Statistical } \\
\text { significance }\end{array}$ \\
\hline $\begin{array}{l}\text { The possibility of } \\
\text { measuring the } \\
\text { environmental costs of }\end{array}$ & Male & 3.93 & 0.43 & 2.18 & 29 & 0.03 \\
\cline { 2 - 6 } & Female & 3.62 & 0.23 & & \\
\hline
\end{tabular}

In Table 6, the existence of statistically significant differences is shown between the arithmetic averages of the standard for organizational loyalty, where the $T$-value is 2.18 , which is the value of a function at the significance level of $a=0.05$, with the arithmetic average of 3.93 achieved by the male and arithmetic average of 3.62 by female. 
Table 7

Arithmetic Averages of the Standard Deviations of the Possibility of Measuring the Environmental Costs of Disclosure, Attributed to a Variable Degree

\begin{tabular}{llll}
\hline Area & Degree & Arithmetic average & Standard deviation \\
\hline \multirow{2}{*}{$\begin{array}{l}\text { The possibility of measuring the } \\
\text { environmental costs }\end{array}$} & Diploma & 3.77 & 0.48 \\
& B.s. & 3.82 & 0.3 \\
& Master's degree or above & 3.84 & 0.42 \\
\hline
\end{tabular}

In Table 7, there is virtual difference between arithmetic averages (range of possibility of measuring the environmental costs of disclosure, attributed to a variable degree), and to learn the statistical significance of these differences, the unilateral variance analysis (ANOVA) (the extent of the possibility of the measurement of environmental costs of disclosure, attributed to a variable degree) was applied.

Table 8

The F-value of the Extent of the Possibility of Measuring the Environmental Costs of Disclosure, Attributed to a Variable Degree

\begin{tabular}{|c|c|c|c|c|c|c|}
\hline Area & $\begin{array}{l}\text { The source of the } \\
\text { variance }\end{array}$ & $\begin{array}{l}\text { The total } \\
\text { boxes }\end{array}$ & $\begin{array}{l}\text { Degrees of } \\
\text { freedom }\end{array}$ & $\begin{array}{l}\text { Medium } \\
\text { boxes }\end{array}$ & $F$-value & $\begin{array}{l}\text { Statistical } \\
\text { significance }\end{array}$ \\
\hline \multirow{3}{*}{$\begin{array}{l}\text { The extent of the possibility of } \\
\text { measuring the environmental } \\
\text { costs of disclosure }\end{array}$} & Between groups & 0.01 & 2.00 & 0.01 & & \\
\hline & Within the groups & 4.62 & 28.00 & 0.16 & 4.04 & 0.9 \\
\hline & The total & 4.6 & 30.00 & & & \\
\hline
\end{tabular}

Table 8 shows that the $F$-value of the extent of the possibility of measuring the environmental costs of disclosure is 4.04, which is the value of the function at the non-statistically significant level of $a=0.05$, indicating the absence of statistically significant differences between the arithmetic averages of the possibility of measuring the environmental costs of disclosure, attributed to a variable degree.

In Table 9, there is a virtual difference between arithmetic averages (range of possibility of measuring the environmental costs of disclosure, attributed to a variable monthly income), and to learn the statistical significance of these differences, the unilateral variance analysis (ANOVA) (the extent of the possibility of the measurement of environmental costs) was applied.

Table 9

Arithmetic Averages of the Standard Deviations of the Possibility of Measuring the Environmental Costs of Disclosure, Attributed to a Variable Monthly Income

\begin{tabular}{llll}
\hline Area & Monthly income & Average & Standard deviation \\
\hline \multirow{2}{*}{$\begin{array}{l}\text { The possibility of measuring the the than 250 dinars } \\
\text { environmental costs }\end{array}$} & 251-450 dinars & 3.94 & 0.55 \\
& More than 451 dinars & 3.81 & 0.36 \\
\hline
\end{tabular}

Table 10

The Results of the Application of the Unilateral Variance Analysis of the Extent of the Possibility of Measuring the Environmental Costs, Attributed to a Variable Monthly Income

\begin{tabular}{lllccr}
\hline Area & $\begin{array}{l}\text { The source of the } \\
\text { variance }\end{array}$ & $\begin{array}{l}\text { The total } \\
\text { boxes }\end{array}$ & $\begin{array}{l}\text { Degrees of } \\
\text { freedom }\end{array}$ & $\begin{array}{l}\text { Medium } \\
\text { boxes }\end{array}$ & $\begin{array}{l}\text { Statistical } \\
\text { significance }\end{array}$ \\
\hline $\begin{array}{l}\text { The extent of the possibility of } \\
\text { measuring the environmental }\end{array}$ & $\begin{array}{l}\text { Between groups } \\
\text { costs of disclosure }\end{array}$ & 0.07 & 2.00 & 0.03 & 0.16 \\
\hline
\end{tabular}


As shown from Table 10, the $F$-value of the extent of the possibility of measuring the environmental costs of disclosure, attributed to a variable monthly income is 0.21 , which is the value of the function at the non-statistically significant level of 0.05 , indicating the absence of statistically significant differences between the arithmetic averages of the possibility of the measurement of the environmental costs of disclosure, attributed to a variable monthly income. From the previous results, it is showed that there were statistically significant differences at the significance level of $0.05>0$ in the views of the members of the sample on the possibility of measuring the environmental costs of disclosure, depending on the variable sex, and the absence of statistically significant differences at the significance level of $0.05>0$ in the views of the members of the sample on the possibility of measuring the environmental costs of disclosure, according to qualification degree, monthly income, thereby accepting hypothesis of scientific degree and rejecting the hypothesis of monthly income.

\section{Results}

Based on the above analysis, the results of this research are as follows:

(1) The presence of statistical significance at the level of 0.05 provides that there is a possibility of measuring environmental costs in companies;

(2) The presence of statistically significant differences between the arithmetic averages of the standard for organizational loyalty to the sex variable as the $T$-value is 2.18 , which is the value of a function at the significance level of 0.05 , and differences in favor of males as the arithmetic average (3.93), while the arithmetic average for females (3.62);

(3) There were no statistically significant differences between the arithmetic averages of the possibility of measuring the environmental costs of disclosure, attributed to a variable degree;

(4) There were no statistically significant differences between the arithmetic averages of the possibility of measurement environmental costs attributed to a variable monthly income.

\section{Recommendations}

From the above results and the possibility of measuring the environmental cost, we present the following recommendations:

(1) Care and attention should be given to the measurement of social responsibility and accountability of the various elements to remove the shortage and lack of completeness;

(2) The allocation of the budget to preserve and protect the environment and the budget of social costs;

(3) The development of accounting methods in order to provide environmental information to make sound decisions to exploit these resources;

(4) The work of the mechanism of accounting for environmental costs and the evolution of modern environmental accounting theoretical or application of it not use till now.

\section{References}

A proposal to evaluate alternatives to reduce the emission rate at the enterprise level. Journal of Financial and Commercial Studies, 1998.

Abdul Alim Sobhi Abdul Hamid Nile. (2005). The measurement and analysis of the effectiveness of environmental costs.

Abdulwahab. (1996). The impact of the accounting disclosure on the performance of the economic units in the area of the fight against pollution of the environment on the behavior of decision makers of the decision to invest in stocks, 1996. The comprehensive oversight Magazine 1995.

Abdulwahab. (1996). The impact of the accounting disclosure on the performance of the economic units in the area of the fight against pollution of the environment on the behavior of decision makers of the decision to invest in stocks. 
Abu Zaid. (2007). Proposed accounting framework of disclosure of environmental performance under the environmental quality standards. Framework of Accounting Theory.

Act No. 4 of 1994 issuing a law on the environment, I1, 2007.

Adnan Ahmed Al-samadi. (1987). Approach of Islam in the preservation of the environment from pollution. Journal of Shariah and, Micro-Economics (Concepts and Applications), the Arab edition, translated by Dr. Kamel Salman al-Ani.

Ahmed Abdul Khaleq. (1995). Environmental policies and international trade, comparative study (Study submitted to the Conference Economics of the Environment).

Ahmed Farghali Hassan. (2007). Environmental accounting between the reality of scientific and practical, the modern trends of accounting and auditing under the economic and technological changes.

Ahmed Farghali. Mohammed Hassan. Future studies in environmental and natural resources accounting (General Framework).

Ahmed Mohammed. (1997). Rose bloom, measurement and control costs to prevent pollution from the printing industry.

Amr Hussein Abdul. (1999). The Chinese mainland, the role of the management accountant in the measurement and analysis of environmental costs.

Chang, S. H., Huang, S. Y., \& Lin, Y. C. (2012). Study on environmental accounting construction process of small and medium enterprises: Using film coating company as an example. J. Environ. Manag, 12, 1-25.

Dalia Reza Mustafa. (2004). Accounting for the costs of achieving the environmental and occupational safety.

Ding, X. F. (2009). A study of the influences of environmental accounting and environmental protection to financial performance (Master's thesis, National Taiwan Ocean University, Keelung City, Taiwan).

Ferreira, A., Moulang, C., \& Hendro, B. (2010). Environmental management accounting and innovation: An exploratory analysis. Accounting, Auditing \& Accountability Journal, 23(7), 920-948.

Hady Ahmad Osman. (1989). Cat measuring costs of damage and treatment of industrial pollution.

Halim. (2001). The contribution of the accounting systems in the report and the disclosure of the environmental performance of business organizations.

Hassan Ahmed Shehata. (2007). Environmental pollution and risks of energy.

Hassan Syed Owais Abu Check-in, under the proposal of the measurable impact accounting disclosure, maintain, 2004.

Huy, P. Q. (2014). Exploring the Vietnamese environment accounting with an introduction about the green accounting information system. Journal of Modern Accounting and Auditing, 10(6), 675-682.

Ibrahim Shukri Girgis. (1998). Accounting for environmental costs and the impact of the adoption of the resolution.

International Federation of Accountants. (2015). Retrieved from http://www.ifac.org/

Ismail Othman. (2003). Seeking to cleaner environment. Journal of the Environment Day.

Magda Hussein Ibrahim. (2000). Under the proposal to reduce the costs of production and quality from the perspective of the entrance costs.

Mohamad Tursi. The importance of disclosure of environmental and social responsibility in the financial reports (Published in the Kingdom of Saudi Arabia).

Mohamed Hussein Ahmed Hassan. (1999). Environmental disclosure in the financial reports of positive effects.

Mohamed Ibrahim Mansour. (1995). The role of tax in the fight against pollution and the protection of the environment and trade.

Mohammad Abbas Badawi. (2000). Accounting for environmental impacts and social responsibility project.

Mohammad Ali Sayed. (1998). Economy (environmental entrance).

Mohammad Mousa Othman. (1998). Environmental pollution and its impact on economic development.

Mohammad Nabil Alam. (1996). Subject to social performance costs at the level of the organization of the actual measurement.

Mohammad. The Islamic perception of environment and dimensions of the Egyptian-Sudanese. Journal of Shariah and Islamic Studies.

Moorthy, K., \& Yacob, P. (2013). Green accounting: Cost measures. Open Journal of Accounting, 2(1), 4-7.

Nofan Hamed. (2010). Accounting measurement of the costs of environmental pollution damage to workers in the oil refinery sector.

Porter, M. E. (2009). Game theory (2nd ed.). Commonwealth Publishing, Co. Ltd.

Safaa Muhammad. (2000). Entrance of a proposal to assess the environmental performance of the fifth dimension in the system of balanced performance. (BSC) MAGDA afifi Nasr Shaheen, an assessment of the accounting information system and the pharmaceutical sector for purposes of control and evaluation of performance.

Shawqi Mr. (2003). Toward a national environmental action plan. Journal of the Nile (Environment and Development).

U.S. Division for Sustainable Development. (2015). Retrieved from http://www.un.org/esa/sustdev/index.html

Zaki.alsayed. (2007). Quantitative measurement of the impact of the accounting disclosure of environmental information to users of financial statements. 